\title{
Istanbul 2004
}

\author{
By Gönül Dönmez-Colin
}

Fall 2004 Issue of KINEMA

\section{ISTANBUL INTERNATIONAL FILM FESTIVAL 2004}

The International Istanbul Film Festival celebrated its $23^{\text {rd }}$ birthday between 10-25 April, 2004 with almost 200 films from around the world. The most successful films of the year were showcased in the main programme, which comprised the National and International Competition; Young Stars of the World Cinema; Cinema, the Mirror of Our Times and From the World Festivals sections.

Since the 1980 closure of the Turkish cinematheque (founded in 1965 by a small group of art-loving intellectuals) by the military regime of the epoch, the festival has shouldered the dual role of preserving the film heritage through several homages and tributes in the sidebars. Among the film personalities receiving tributes are Werner Herzog and Klaus Kinski, Ken Russell, Bahram Bayzai, John Cassavetes and Turkey's only real auteur, Ömer Kavur. Marco Ferreri was this year's "cult figure" with four of his films. Greek master Theo Angelopoulos, a regular of the festival, presented five of his favourites. "A Country - A Cinema" section focused on Latin America with 15 recent films from the area.

In the International Competition section, fourteen feature films with some relation to art and the artist (or adaptations from literary works) competed for the coveted Golden Tulip. Bu San (Goodbye, Dragon Inn) by Tsai Ming-Liang from Taiwan, Alila by Amos Gitai from Israel, Noviembre (November) by Achero Manas from Spain and Bekleme Odasi (The Waiting Room) by Zeki Demirkubuz were some of the noteworthy entries.

The twelve films in the National Competition were generally works by young filmmakers. A courageous film was Inat Hikayaleri (Tales of Intransigence) by Reis Çelik, shot with the local people of a village in Eastern Turkey under harsh weather conditions. The only professional in the film was the veteran Turkish actor of international fame, Tuncel Kurtiz. The film was an attempt at carrying the tradition of storytelling onto the screen and the visual aspects were stunningly beautiful.

Another visually impressive film was Yesim Ustaoglu's Bulutlari Beklerken (Waiting For the Clouds). Ustaoglu, who has won several awards with Günese Yolculuk (Journey to the Sun), the story of an unusual relationship between a Kurd and a Turk focused on a sad part of Turkish history, the deportation of the Greeks during World War I, foregrounding the search for national and personal identity through a painful voyage into history.

Clamur (Mud) by Dervis Zaim looked at the suspended lives of youth in divided Cyprus. The Waiting Room, the final episode of the trilogy that has included Yazgi (Fate) and Itiraf (Confession) focused on a self-centred, egoistical, anti-social filmmaker (played by Demirkubuz) who went to extremes in his search for an actor to play Raskolnikov in the film he wanted to make on Dostoevsky's classic novel Crime and Punishment.

On a lighter note, Insan Nedir ki? (What's a Human Anyway?) by Reha Erdem and Vizontele Tuuba by Yilmaz Erdoğan were both crowd pleasers. The latter is the biggest box office hit among Turks everywhere.

The best of the twelve, according to most viewers was Karpuz Kabugundan Gemiler Yapmak (Boats out of Watermelon Rinds), the first film by autodidact Ahmet Uluçay. In this largely autobiographical film that begins like Cinema Paradiso but succeeds in telling a moving story imbued with local colour, Uluçay tells the story of two village boys growing up in the late 1960s. The boys are in love with the movies, but the film is not only about their cinematic experiments and dreams, but also about their first experiences in work and love. The cast is comprised entirely of the local people of Tavşanli, the filmmaker's hometown, which serves as location to a large part of the film. 


\section{References}

\section{AWARDS}

International Competition

Golden Tulip for the Best Film

Bu San (Goodbye, Dragon Inn) by Tsai Ming-Liang

Special Prize of the jury (ex aequo)

Profesionalac (The Professional) by Dušan Kovačević (Serbia-Montenegro) and L'Esquive by Abdellatif Kehiche (France)

National Competition

Best Turkish Film of the Year Award

Karpuz Kapugundan Gemiler Yapmak (Boats Out of Watermelon Rinds) by Ahmet Uluçay

Best Director of the Year Award

Zeki Demirkubuz for Bekleme Odasi (The Waiting Room)

Best Actor Award (ex aequo)

Emre Kinay and Sevket Çoruh for successfully complementing each other's performances in Insaat (Under Construction) by Ömer Vargi

Best Actress Award

Rüçhan Çaliskur for her performance in Bulutlari Beklerken (Waiting for the Clouds) by Yesim Ustaoglu

Special Prize of the Jury

Bulutlari Beklerken (Waiting for the Clouds) by Yesim Ustaoglu

FIPRESCI Awards

International Competition

L'Esquive by Abdellatif Kechiche (France)

National Competition

Insan Nedir ki? (What is Human Anyway?) by Reha Erdem

\section{Author Information}

Gönül DÖNMEZ-COLIN is an independent researcher and writer whose publications include Women, Islam and Cinema, Cinemas of the Other: A personal Journey with Filmmakers from the Middle East and Central Asia, Cinema of North Africa and the Middle East (ed.); Turkish Cinema: Identity, Distance and Belonging (Reaktion Books), and Routledge Dictionary of Turkish Cinema (2014). 